exists between the Truro and Wellfleet plains, the latter presenting steep ice-contact (?) slopes towards the northwest.

South of North Truro village, however, the lower plain joins on directly to the higher. Kettle holes are common. Standing upon the high ground a mile north of Truro station and looking east, the whole series of plains seems to descend by a gentle delta (?) slope toward the west, leaving a deep and irregular depression occupied by the Provincetown turnpike. In the vicinity of Small's Hill a number of profound northeast and southwest depressions dissect the plain. These are occupied by the roads leading to the east shore. The slopes on both sides of these depressions are steep, and although they probably have been modified by wind the indications are that they are due to former lobes of ice dissecting the growing delta. Pamet River completely divides this series of plains, the southern portion being much more irregular and hummocky than the northern and also containing a number of kettle ponds.

The Eastham Plains are typically developed about North Eastham village. This series may be better regarded as one continuous plain uniform along the eastern shore from Wellfleet to the 'Three Lights,' where the elevation is about seventy-five feet above the sea, and the whole plain gently sloping westward. The northern half of this large plain is dissected by discontinuous east and west, and northwest and southeast depressions, with steep icecontact (?) slopes on the south and lobate delta (?) slopes on the north. In the southern half of the plain the depressions have a north and south trend, with the steep icecontact (?) slopes on the west and the delta (?) slopes on the east. South of Eastham Centre the plain joins on to the moraine. This plain was probably formed while the Truro Plains were accumulating and after the Wellfleet Plains had been formed. The latter seem to have been built by streams from the north and east. The Truro plains were built by streams from the northwest and northeast, while the Eastham Plain was being built by streams from the east. The terminology is applied to the slopes with some reservation, as almost the only criterion by which to judge of their character is the relative steepness and the general outline. Cuttings are very rare, and hence the relative coarseness of the material, and its disposition within the plains cannot be ascertained. The sections along the shore exhibit horizontal stratification where not covered by talus.

It seems difficult to believe that these plains have not accumulated in static water at the front of the much-dissected ice sheet. Submarine accumulation seems improbable, as erosion scarps would have been formed on the higher plains during the formation of the lower. On the other hand, if a body of fresh water was held up against the moraine, in an embayment in the ice front, it would be necessary to suppose that the ice held on to the moraine from Barnstable eastward, and that a residuary plug of ice filled the valley of Buzzard's Bay. This latter necessity is probably the most serious defect of the glacial lake theory.

Amadeus W. Grabau.

\section{A NEW METHOD OF DRIVING AN INDUCTION COIL.}

Since the induction coil has come into prominence through the discovery of the $\mathrm{X}$-rays of Röntgen considerable attention has been turned toward devising some means which is applicable to long runs, on a voltage such as is furnished by electric light mains, 110 or 220 volts. The more recent forms of break work well with storage batteries, but these are troublesome, and a break which will work satisfactorily on the voltage of ordinary electric-light mains is 
yet to be supplied. The following method has been devised to meet these difficulties :

A condenser of considerable capacity is first connected to the lighting mains and charged at 220 volts. It is then disconnected and discharged through the primary coil. The charging and discharging of the condensers is effected by means of a commutator. In this way the only current passing through the coil is from the condenser. The commutator is on the shaft of a small fan motor.

A six-inch Ritchie coil connected in this way with a condenser of 25 microfarads, its own condenser being disconnected, gives a thick fuzzy spark about two inches long. Removing the primary of the coil and replacing it by about seventy turns of rather heavy wire, number 8 or 6 B. \& S., we get a multitude of fine zig-zag sparks about six inches long, the discharge being identical in appearance with that from an induction worked in the ordinary manner under the best conditions. The introduction of iron, unless finely laminated, cuts down the discharge to about one-tenth its value. Increasing the speed of the charge and discharge of the condenser up to about 2,000 per minute, which is the limit of the very crude commutator at present employed, improves the discharge of the coil in quantity and voltage. The sparking on the commutator is very slight, and the amount of power taken from the mains is small.

The discharge obtained in this way, so far as we can now judge, seems well suited for driving X-ray tubes. Tubes so driven give a brilliant fluorescent screen with strong sharp shadows. An exposure of twenty seconds gives a good photograph of the hand.

Chas. L. Norton, Ralph R. Lawrence.

Rogers Laboratory of Physics, Mass. Institute of Technology, Boston, February 17, 1897.
CURRENT NOTES ON PHYSIOGRAPHY.

THE COLORADO PLAINS.

An essay by Gilbert on the ' Underground Water of the Arkansas Valley in Eastern Colorado' (17th Ann. Rep. U. S. Geol. Surv.) affords more specific information as to the topographic features of the plains and their origin than is usually obtainable from older reports. The general surface of the plains does not accord with the surface of their uppermost stratum, but bevels across the strata at a faint angle. The plains are therefore not in topographic youth, but in topographic old age, the result of a cycle of denudation during a lower stand of the land. On the peneplain thus formed there are now strewn the ' upland sands,' pebbly, cross-bedded, 50 to 200 feet thick; the pebbles being derived from the mountains on the west. This implies a period of aggradation, after the long preceding degradation. In explanation of the change it is suggested that the region may have been raised in the east or depressed in the west so as to lessen the slope of the rivers; to this there may be added a possible uplift of the mountains alone by which the load of the rivers would have been increased. To-day the sand-strewn peneplain is trenched by broad valleys, that of the Arkansas being fifteen or more miles wide and 400 to 800 feet deep. Successive pauses in the work of valley-cutting produced broad straths at lower and lower levels, whose remnants are now seen in gravel-covered terraces, the seat of much irrigated land. The eastward slope of the terraces is greater than that of the present grade of the river; hence a progressive uplift is argued during the excavation of the valley. The upland sands and the stream beds at low water supply sand to the northwest winds and extensive patches of dunes are thus formed, a system of hills and hollows without drainage by streams. The relation of Cretaceous strata, upland sands 